\title{
YOUTH INVOLVEMENT IN RURAL DEVELOPMENT ACTIVITIES IN OGBA DISTRICT OF RIVERS STATE, NIGERIA
}

\section{Obuh James}

\begin{abstract}
The importance of youth involvement in rural development needs be emphasized. This is because they are major stakeholders in the development process. This study investigates youth involvement in rural development activities in Ogba district of Rivers state, Nigeria. Data was collected from 120 randomly selected youths in the study area. Data collection was by the use of structured questionnaire and interview and data analysis was through the use of frequency, percentage and mean. Findings revealed that youths were more involved in activities concerning building town halls, formation of vigilante group, erecting pipe-borne water facilities, and fishing/farming activities. The major problems affecting their involvement in rural development include Low level of exposure, Poor leadership, Lack of cooperation among youths, Insufficient funds from government, Lack of encouragement from elders, Inadequate motivation from environment.
\end{abstract}

\section{Key words: youth involvement, rural development activities}

\section{INTRODUCTION}

In any development project, participation is of paramount importance which must include the community development committee fosters and promotes, has been variously acknowledged as a most rewarding development strategy. Participation must be sought from both within and outside community. If the community initiates a project (usually through her CDC), the participation of all community members must be sought. Also, if an external development mission institutes the community project, popular participation goes to both the community member who refuses to participate and the external development mission that refuses to all for participation. Obibuaku (1983) has stressed the fact that people appreciate a program better and are more likely to support it if they participate in planning it. This no doubt, explains the basis for some professional views in support of local participation in project planning and execution (Williams et. al 1984).

Anyanwu (1992) stated that there is usually a sense of sell worth and a feeling of selffulfillment on community members when they see themselves as part and parcel of efforts towards their own welfare. Ogolo (1995) stated that local participation in whatever community project (or a programme) would also guarantee the project's ( or program) sustainability. Smith (1984) pointed out the fact that when projects are conceived, designed, planned and managed entirely by non-community members, there is the tendency on the part of the recipient to reject, ignore of misuse the resulting facilities. The cause of massive vandalization of infrastructure especially in the rural communities could also be explained along this line. The promotion of a participatory community development process may make a difference in the nations rural communities by fastening the rate of the provision of basic amenities in the community and ushering in a cordial development process. Shingi et al (1980) reported that in spite of the fact that youth constitute a dynamic force in any given society, youth as a concept for scientific studies is relatively low. He stated that rural youth works in developing countries are seldom undertaken by the youths, while work, organized by the adults often suffer from insufficient involvement of the youth themselves. In both planning and execution. This means that the programs have difficulty in realizing their objectives.

In their own view, Shingi et al (1980) stated that common man, however regards 
youth as a student of higher education and is partly because the news media frequently interchanged topics like "Student Unrest" and "Youth Unrest". They believed that youth represents a specific age bracket in the total lifespan of a person whereas some other believe that the concept of youth is not necessarily related to the biological age structure, but is a state of mind, and thus a matter of inference, Shingi et al (1980) posited that psychologist however view youth as a state of readiness in which the individuals total energies and potentials are unable to find full employment. According to them any person who is energetic and alert can be regarded as youthful, irrespective of his age. Olayide et al (1981) cited Nigeria where the rural youths account for about seventy-five percent of the total population. As a result, rural development has been said to be one of the approaches for rural transformation, that is, it is one of the measure or steps which can be taken in order to bring about improvement in the area of social, economic, political and cultural condition of a community. The youths readily become veritable tool that can enhance accomplishment of community goals.

However, according to Shingi et al (1980), operational simplicity, however, guided most of the resources to define youth as any person in the age-group of 10 to 30 years. The United Nations Statistics on children and youth (1968) for instance posited that any person between 15 and 24 years is in the category of youths. Whereas the Minister of Education and Youth Service, (1969) in one of its conferences defined youth as anybody in the age group of 16 to 30 years. Furthermore, it has been agreed upon on the broad concept that youth is a transitional period in personality development and it bridges the years between childhood and adulthood (D'Souza, 1970). In this opinion 10 years of age is really the bottom of the range and 24 years and above a bit on the higher side.

Despite the fact that there is pressing need to develop the rural sector because of its importance in the nations development, youths that constitute part of the population that make up the rural area do not know how they can contribute to the development of their area. Those who know that there is need for them to play significant role in the socio economic development of their localities do not know how to go about it.

However, this research intends to investigate the extent to which youths are involved in rural development in their area. Specifically the study intends to identify the demographic characteristics of rural youths in the study area, determine the level of involvement of rural youth in development programmes, and determine the problems faced by youths in their involvement in rural development activities.

\section{METHODOLOGY}

The study area is the Ogba district of Rivers State which is a significant part of the state because the area is a major producer of crude oil from where the nation gets a fair share of revenue. The population for the study consists of youths in the Ogba district of Rivers State. Thirty youths were randomly selected from four communities using both structured questionnaire and interview schedule to give a total of one hundred and twenty (120) respondents. The instrument elicited information on demographic characteristics, level of involvement in rural development activities and problems affecting youths involvement in rural development activities. Both open and closed ended questions were utilized for data collection.

In order to obtain information on rural development activities, respondents were requested to rate their level of involvement in ten rural development activities based on a three point scale of high involvement, moderate involvement and low involvement. As for information on problems affecting involvement, respondents were requested to rate nine perceived problems on a three point scale of very important, moderately important and not important.

For the purpose of interpreting data, a mid-point of 2.00 was established and it was 
noted that any mean score that was equal to or greater than 2.00 was accepted to mean high involvement and any mean score that was less than 2.00 was accepted to mean less involvement. Meanwhile, for the problems affecting involvement in rural development activities, any mean score that was equal to or greater than 2.00 was accepted to mean serious problem while any mean score that was less than 2.00 was accepted to mean less serious problem. Data analysis was mainly through descriptive statistics such as frequency, percentage and mean.

\section{RESULTS AND DISCUSSION}

Table 1: Demographic characteristics of respondents $(n=120)$

\begin{tabular}{lll}
\hline Characteristics & Frequency & Percentage \\
\hline Gender & 67 & 55.8 \\
Male & 53 & 44.2 \\
Female & & \\
Age & 12 & 10.0 \\
<20 years & 56 & 46.7 \\
20-25years & 26 & 21.7 \\
26-30years & 16 & 13.3 \\
31-35years & 10 & 8.3 \\
Above 35years & & \\
Marital status & 69 & 57.5 \\
Single & 51 & 42.5 \\
Married & & \\
Occupation & 49 & 40.8 \\
Student & 20 & 16.7 \\
Civil servant & 27 & 22.5 \\
Business & 24 & 20.0 \\
Applicant & & \\
Education & 3 & 2.5 \\
None & 19 & 15.8 \\
Primary & 53 & 44.2 \\
Secondary & 45 & 37.5 \\
Higher & &
\end{tabular}

Table 1 shows that majority of the respondents involved in the study were males, and were between 20 and 25 years. This age category is an active period in the lives of youths generally and as such it is expected that they should be able to exert adequate physical energy to development activities. Ajaero and Njoku (2005) found that the mean age of youths in their study was 21.8 years. This study showed that majority of the respondents was single and were mainly students. This was further confirmed as findings revealed that majority of the respondents were educated with a higher percentage attaining secondary education. 
Table 2: Mean distribution of respondents according to development activities involved in $(\mathbf{n}=120)$

\begin{tabular}{lll}
\hline Development activities & Mean score & Rankings \\
\hline Town halls & 2.43 & 1 \\
Vigilante group & 2.42 & 2 \\
Erecting pipe-borne water & 2.33 & 3 \\
Fishing/farming & 2.25 & 4 \\
Schools & 1.96 & 5 \\
Road construction & 1.92 & 6 \\
Pressure group for employment of youths & 1.87 & 7 \\
Encouraging education through debates & 1.83 & 8 \\
Settling disputes & 1.79 & 9 \\
Constructing bus stop & 1.75 & 10 \\
\hline
\end{tabular}

Ten rural development activities were identified from the study. Ranking these activities revealed that four activities were more significant. The first ranking was for building of town halls. The importance of town halls to the inhabitants of the rural areas in the study area cannot be overemphasized. This is because the town halls are the meeting points for most community deliberations. The next ranking was for formation of vigilante groups. This activity has become inevitable in the rural and urban communities because they serve as security outfit, complementing the efforts of the Police and being more active at nights. The third most important activity identified was erecting pipe-borne water facilities. Youths have been very much involved in this development effort especially when they are supported by multinationals that are common in the area.

Fishing/farming activities were ranked fifth among the rural development activities identified. Many inhabitants of the study area are involved in farming and to a large extent fishing, since streams and rivers are commonplace in the area. Fishing and farming are therefore common means of livelihood among the people.

Table 3: Problems affecting involvement of youths in rural development activities

\begin{tabular}{lll}
\hline Problems & Mean score & Rankings \\
\hline Low level of exposure & 2.78 & 1 \\
Poor leadership & 2.71 & 2 \\
Lack of cooperation among youths & 2.64 & 3 \\
Insufficient funds from government & 2.63 & 4 \\
Lack of encouragement from elders & 2.39 & 5 \\
Inadequate motivation from environment & 2.26 & 6 \\
Insufficient training & 2.21 & 7 \\
High input but low output & 2.18 & 8 \\
Few opportunities & 1.92 & 9 \\
\hline
\end{tabular}

Youths involvement in rural development is hampered by various problems as revealed by the findings of the study. Nine problems were identified in this study. The most serious problem identified by respondents was low level of exposure. This finding is expected because many respondents stated that they have not traveled out of their community. It is possible that this may influence their perception about rural development. Exposure to other culture is a factor that influences change (Ekong, 2003). Poor leadership was identified as the next most serious problem. By this, they expressed that the national leadership is not providing adequate direction for them to participate in development activities, especially in the rural areas. 
Insufficient fund from government was identified as the third problem affecting youth involvement in rural development. Government, it was noted was not providing enough funds to development the rural areas and that is why the rural areas are still far from developing. The next serious problem ranked as fourth was lack of cooperation from youths. This could be because of the rural-urban migration mostly experienced by youths. Angba (2003) revealed that migration of youths from the rural areas has serious implication for agricultural production since most of the work that would have been done by the youths are now left for the adults to do. It was noted that migration would create additional burden of transferred tasks to the adults. Findings of the study showed that lack of encouragement from elders was ranked as the fifth problem affecting involving in rural development activities. This was followed by inadequate motivation from environment. This is expected because of the poor nature of rural development experienced by the youths in their communities. Insufficient training, high input but low output and few opportunities ranked seventh, eight and ninth respectively.

\section{CONCLUSION AND RECOMMENDATIONS}

Youths are potent force to reckon with when issues of rural development are being discussed. This is because of their large numbers that is being exploited for communal participation in development activities. Their contributions to development activities can therefore not be overstated. This study investigated their involvement in rural development activities in Rivers State. It was found that they were actively involved in activities concerning building town halls, formation of vigilante group, erecting pipe-borne water facilities, and fishing/farming activities. Based on the findings of this study, the following is recommended:

1. Youths should be actively involved in decision making through the execution of the programmes so that their contributions to rural development can be reasonably appreciated

2. Rural youth organizations should be made more viable to partake in useful development activities and the youths should be motivated to participate in youth organizations for them to be able to contribute to community development programs

3. Adequate awareness should be created on the recent and past projects developed. To this end, government should strengthen these youth organizations in the communities.

\section{REFERENCES}

Ajaero, J.O. and Njoku, N.J. (2005) Agriculture Undergraduates' preference for Agriculture disciplines in Federal University Of Technology, Owerri, Nigeria. Global Approaches to Extension Practice, 1 (1), 18-23.

Angba, A. O. (2003) Effect Of Rural-Urban Migration Of Youths On Agricultural Labour Supply In Umuahia North Local Government Area Of Abia State, Nigeria. Journal Of Agriculture And Social Research, 3 (2)

Anyanwu C.N. (1992) Community Development The Nigeria Perspective. Gabester Educational Publishers, Ibadan. P 77

D'souza AA.(1970) Multipurpose School, Its Theory And Practice. Bombay: Elite Publisher. Publishers

Ekong E. E. (2003) An Introduction To Rural Sociology. Uyo, Nigeria: Dove 
Ministry of Education A Youth Service (1969) in one of its conference.

Obibuaku L.O. (1983) Agricultural Extension As a Strategy For Agriculture Transformation. University of Nigeria Press $\mathrm{p} 81$.

Ogolo M.B.(1995) "Grassroots Participation in Rural Development: A study of Selected Infrastructure in Some Communities of Rivers State Nigeria" Unpublished PhD Dissertation, Department of Agricultural Extension Services, University Of Ibadan, Nigeria pp270.

Olayide S.O. Ogunfowora, O Essang, S. M. and Idachaba, F.S.(1981): Element of Rural Economics I.U.P. p.!3-21.

Shingi P.M Singh N.P.and Jadhav D.(1980) Rural Youth Education Occupation And Social Outlook. Abhinar Publication, New Delhi. pp109

Smith P.J.(1987) "Identifying Better Development Project A System Approach" Agricultural Administration Vol. 25 No 1 pp13-14. 